\title{
Maaseutuhallinnon arjen todellisuus - puhetta byrokraattisuudesta
}

\author{
Päivi Kujala
}

\begin{abstract}
The everyday reality of rural administration - talk about bureaucracy

The article analyses bureaucratic discourse in everyday rural administration, utilising Max Weber's bureaucratic theory and the notions of dysfunctional bureaucracy by Robert K. Merton. The word bureaucracy has a negative connotation in implementing business funding within partially EU financed rural development programmes. The research contains 38 interviews with rural administration actors and entrepreneurs. Critical discourse analysis revealed three discourses: law obedience, programme as a host and wholeness missing. The results established that the bureaucratic model of rural administration produces many undesired consequences.
\end{abstract}

Keywords: bureaucracy, rural administration, discourse, decision-maker, entrepreneur

\section{JOHDANTO}

Tämän tutkimuksen liikkeellepanevana voimana on ollut tavoite ymmärtää termin byrokratia alkuperäinen merkitys. Byrokratia on saanut nyky-yhteiskunnassa lähes yksinomaan negatiivisen leiman erityisesti maaseutuhallinnon toimijoiden, yrittäjien ja suuren yleisön keskuudessa. Byrokratian haitat ja häiriötekijät ovat kasvaneet arjen käytännöissä ja kokemuksissa hyötyjä suuremmiksi (vrt. Merton 1968). Arjen puhunnassa byrokratia on kääntynyt puheeksi byrokraattisuudesta, haittoja kuvataan muun muassa sanoilla paperisota, tiukat käytännöt, kankeus ja hitaus. Byrokratisoituminen koetaan organisaatioiden uhkaksi ja vaaraksi, näin sanottuna byrokratia ymmärretään huonoksi hallinnoksi (Salmi 2003, 97).
Käytännön kokemus byrokratian ominaisuuksista on muodostunut ristiriitaiseksi Max Weberin määrittelemien byrokratiateorian ideaalimallin erikoisominaisuuksien kanssa, joita ovat täsmällisyys, nopeus, selkeys, tietoisuus menneestä kehityksestä, jatkuvuus, harkintavalta, yhtenäisyys, tiukka alisteisuus ja kitkatekijöiden sekä materiaali- ja henkilökustannusten vähentyminen (Weber 1978b, 973). Weber (1978a, 223) esitti, että kehittynyt byrokraattinen hallinta on rationaalisin ja tehokkain hallinnon muoto. Byrokratia on siten ymmärtäen asioita edistävää hallintoa.

Euroopan unionin jäsenmaana Suomen maaseutuhallinto toteuttaa Euroopan yhteistä maatalouspolitiikkaa (CAP) ja toimeenpanee yhteisten sääntöjen mukaista Manner-Suomen maaseudun kehittämisohjelmaa (maaseutuohjelma). Kansallinen lainsäädäntö ja toimeenpanoohjeistus tukevat EU-tason lainsäädäntöä. Valtiontalouden tarkastusvirasto on todennut tuloksellisuus- ja jälkitarkastukertomuksessaan maatalouden tukihallinnon olevan Suomessa poikkeuksellisen monimutkainen ja raskas myös hallinnollisen taakan näkökulmasta (Paajanen ym. 2013; Männikkö \& Paajanen 2016). Ongelman nähdään johtuvan Suomen harjoittamasta maatalouspolitiikasta ja EU:n vaatimuksista tämän kaltaiselle tukia maksimoivalle politiikalle. Byrokraattisuus on tunnistettu ongelmaksi myös maaseutuohjelman 2007-2013 jälkiarviointiraportissa (Pyykkönen ym. 2015). Hallinnollista taakkaa on aiheuttanut muun muassa sääntöjen muuttuminen kesken ohjelmakauden sekä tukien liian tiukat rajaukset ja joustamattomuus. Ohjelmakauden 2014-2020 ennakkoarvioinnin mukaan ongelmien ennustetaan jatkuvan kuluvalla ohjelmakaudella (Antikainen ym. 2014). Sähköisen asioinnin oletetaan kuitenkin sujuvoittavan tukiprosesseja.

Tavoitteenani on tässä artikkelissa kriittisen diskurssianalyysin keinoin selvittää, millaisia 
byrokratiaa kuvaavia diskursseja rakentuu maaseutuhallinnon toimijoiden ja yrittäjien puheessa heidän puhuessa maaseutuohjelman yritystukien valmistelusta ja toimeenpanosta? Diskurssien tulkintakehikkona toimii Max Weberin määrittelemät byrokratian ideaalimallin erikoisominaisuudet, jolloin tutkimuksen tarkastelun kohteeksi muodostuu myös millä tavalla arjen puhunta vastaa Weberin ideaalimallin ominaisuuksia ja millä tavalla tunnistetut diskurssit heijastelevat byrokratian ei-toivottuja seurauksia? Salminen ja Kuoppala $(1983,57)$ kysyvät Max Weberin verstehen-metodin käytön tutkimuksessaan, onko byrokratia kuitenkin palautettavissa viime kädessä yksilöiden toiminnaksi ja miten siitä kehittyy tai väitetään kehittyvän yksilön ulottumattomissa olevan tekijän? Tutkimusaineisto koostuu Suomessa vuoden 2016 aikana tekemistäni 38 valtakunnallisten, alueellisten ja paikallisten maaseutuhallinnon viranomaisten, yrittäjien, tutkijoiden sekä poliittisten päättäjien puolistrukturoiduista teemahaastatteluista.

Tarkastelen byrokratian ilmiötä hallinnon makrotasolla, jolloin huomio kiinnittyy hallintaan, palvelujen organisointiin ja virkamiehistön toimimiseen yhteiskunnan palvelijana (Salminen 2004, 199). Tutkimuksen lähtökohtana olevan sosiaalisen konstruktionismin makrotason tarkastelussa analyysin keskiössä on valta ja hallitseva asema kielenkäytön yksityiskohtaisuuden sijasta (Burr 2015, 25). Diskurssien sisällä tarkastelen, kuinka tukipäätöksentekijät ja asiakkaana olevat yrittäjät asemoituvat yritystukiprosessissa, koska päätöksenteko voidaan määritellä hallinnon ydintoiminnoksi (Salminen 2004, 85). Tuki- ja maksupäätösten tekijöinä toimivat alueellisten ELY-keskusten maaseutuohjelmaa toimeenpanevat ja asiakaspalvelua tekevät viranomaiset.

Tieteellisiä tutkimuksia Suomen maaseutuhallinnon toiminnasta on tehty vain vähän. Aihetta sivuavia tutkimuksia on tehty Leadertoimintatavan osalta (Salmi 2003; Viinamäki ym. 2013). Kipupisteiksi osoittautuivat muun muassa ohjelmakauden kuluessa tehdyt ohjeistuksen ja sääntöjen muutokset sekä toimintaryhmien yksityiskohtainen seuranta ja valvonta. Euroopan unionin yhteisen maatalouspolitiikan vaikuttavuutta suhteessa politiikalle asetettuihin tavoitteisiin on analysoinut tutkimuksessaan
Arovuori (2015) ja Vihinen (2001). Byrokratian purkamista maaseutuohjelman yritystukien osalta on selvittänyt Suomela (2008) ja Kivikko ym. (2009). Juha Sipilän hallitusohjelman (Valtioneuvosto 2015) myötä norminpurkutyötä on tehty laaja-alaisesti eri hallinnon aloilla, myös yritystukien näkökulmasta (ks. Uusikylä ym. 2018) ja myös maatalouden kannattavuuteen liittyvä Karhisen (2019) selvitys tukee byrokratian purkamisen tavoitteita.

Tässä tutkimuksessa tunnistettavan kolmen diskurssin myötä voidaan todeta, että byrokratian dysfunktionaaliset ominaisuudet ovat maaseutuhallinnon toiminnassa vallitsevia piirteitä. Rakenteellisten muutosten lisäksi tarvitaan toimintatapojen muutosta niin, että byrokratia voidaan palauttaa välineeksi, joka palvelee asiakasta ja samalla luo kevyemmän hallinnollisen taakan sekä yrittäjille että viranomaisille. Tutkimuksen voidaan katsoa tukevan norminpurkutyötä, vaikka tutkimuksessa ei tehdäkään yksittäisten normien purkuehdotuksia.

\section{MAASEUTUHALLINNON OMINAISPIIRTEITÄ}

Maaseutuhallinnon toimijat koostuvat Suomessa maa- ja metsätalousministeriöstä, vuonna 2019 perustetusta Ruokavirastosta (371/2018) - aiemmin Maaseutuvirasto (666/2006), vuonna 2009 perustetuista viidestätoista alueellisesta elinkeino- liikenne- ja ympäristökeskuksesta, ELY-keskus (897/2009) ja vuonna 2010 muodostetuista 64 kuntien yhteistoimintaalueista (210/2010). Suomessa on lisäksi 54 Leader-ryhmää, jotka osallistuvat maaseutuohjelman kehittämistyöhön. (MMM 2019.) Maaseutuhallinnon viranomaisten toimintaa ohjaa valtionhallinnon vuonna 2007 määritellyt kahdeksan eettistä arvoa, jotka ovat avoimuus, laatu ja asiantuntemus, luotettavuus, objektiivisuus, palvelu- ja asiakaslähtöisyys, riippumattomuus, tasa-arvo ja tuloksellisuus (Peiponen 2007).

EU:n yhteisen maatalouspolitiikan mukaista maaseudun kehittämistoimintaa toteutetaan Suomessa Manner-Suomen ja Ahvenanmaan maaseudun kehittämisohjelmien puitteissa. Maaseutuohjelmat ovat EU-ohjelmakauden mittaisia ja noudattavat EU:n antamia strategisia suuntaviivoja. Manner-Suomen maaseudun kehittämisohjelman 2014-2020 avulla tähdätään elinvoimaisen maaseudun säilymiseen, ympä- 
ristön tilan paranemiseen ja uusiutuvien luonnonvarojen kestävään käyttöön. Ohjelman kriteerit täyttävät yritykset voivat saada ohjelman mukaista perustamis- tai investointitukea. (MMM 2019.) Jäsenmaat ovat sitoutuneet myös Euroopan komission (2010) Eurooppa 2020 älykkään, kestävän ja osallistavan kasvun strategiaan.

Maa- ja metsätalousministeriö toimii ohjelman hallintoviranomaisena ja vastaa maaseutuohjelman laadinnasta, toimenpiteiden suunnittelusta, lainsäädännöstä sekä rahoituksen jaosta alueiden käyttöön. Ruokavirasto - aiemmin Maaseutuvirasto toimii maksajaviranomaisena ja vastaa tukien toimeenpanon ohjeistamisesta, sähköisestä asioinnista, tietojärjestelmistä sekä tukien maksamisesta ja otantatarkastuksista. ELY-keskukset vastaanottavat yritystukihakemukset ja päättävät tuen myöntämisestä sekä tuen maksamisesta. ELY-keskukset tekevät tukipäätökset myös Leader-ryhmien rahoittamien yritysten investointien osalta. Kuntien maaseutuhallinnon yhteistoiminta-alueet ja elinkeinoyhtiöt toimivat yritystukien osalta neuvonantajana yrittäjille. Euroopan komissio hyväksyy kansallisen maaseutuohjelman ja tekee myös tarkastuksia jäsenmaissa. (MMM 2019, Tarasti 2016.) Maaseutuohjelmia arvioidaan Euroopan komission ohjeiden mukaisesti. Arviointien tarkoituksena on tuottaa käyttökelpoisia ja ajankohtaisia päätelmiä ja politiikkaa koskevia suosituksia (Antikainen ym. 2014).

\section{TEOREETTINEN VIITEKEHYS}

Tutkimuksen teoreettisen viitekehyksen keskeisiä käsitteitä ovat byrokratia, byrokratiateorian ideaalimallin erikoisominaisuudet sekä byrokratian dysfunktionaaliset ominaisuudet. Lisäksi tarkastelen byrokraattisen hallinnon ja byrokraattisuuden suhdetta.

\section{Byrokratia}

Sana byrokratia tarkoittaa Ranskan akatemian vuoden 1798 sanakirjamääritelmän mukaan hallinnollisten virastojen johtajien ja henkilökunnan vaikutusvaltaa (Albrow 1970, 17). Pysyvä hallintokoneisto, byrokratia, oli jo todellisuutta kaikissa kehittyneimmissä maissa 1900-luvun alussa (Vartola 1979, 12). Weber (1978a, 215) oli kiinnostunut kysymyksestä, miksi ihmiset tottelevat ja erotti sitä tutkiessaan hallintokulttuurin kehittymisessä kolme laillisen vallan tyyppiä. Ensinnäkin luonteeltaan rationaalinen hallinta, mikä perustuu säädettyjen lakien noudattamiselle ja on ominaista byrokraattisen hallinnan mallille, toiseksi traditionaalinen, mikä perustuu ikivanhoihin tapoihin sekä kolmantena yksilön erikoisominaisuuksiin perustuva karismaattinen hallinto. Tiihonen ja Ylikangas (1992, 238) luonnehtivat suomalaista 1900 -luvun hallintoa weberiläiseksi byrokratiaksi. Voidaan todeta, että julkisen hallinnon organisoituminen on pääosin Weberin byrokratiamallin mukaista edelleen, organisaatioilla on muun muassa hierarkia, päätökset ja säännöt laaditaan kirjallisina ja viranhaltijat ovat valittu tehtäväänsä pätevyytensä perusteella (ks. Weber 1978a, 220-223; Merton 1968, 250).

Hallinnon teoriassaan Weber oli kiinnostunut yhteiskunnallisista lainalaisuuksista ja sosiaalisesta toiminnasta, minkä Weber määrittelee ihmisyksilöiden käyttäytymiseksi, johon käyttäytyjät sitovat omakohtaisia ja toisten yksilöiden käyttäytymisen huomioon ottavia merkityksiä (Ahonen 1989, 66). Organisaatioiden kehittämisen näkökulmasta Weber halusi ymmärtää sitä, kuinka organisaatioista tehdään rationaalisia ja tehokkaita, silloin organisaatio ottaa tavoitteekseen kehittyä byrokratiaksi (Harisalo 2008, 128). Byrokratian hyöty modernissa yhteiskunnan kehittämisessä on ollut muun muassa mahdollistaa monimutkaisten asioiden tehokasta täytäntöönpanoa (Smith 1988, 5).

\section{Byrokratian ideaalityypin merkitys ja sen erikoisominaisuudet}

Weberin teorian ydin oli ideaalityypeissä, joita hän kehitti ja käytti metodisena työkaluna yhteiskunnan sosiaalisen toiminnan ymmärtämiseksi. Todellinen toiminta poikkeaa aina puhtaasti rationaalisen toiminnan kulusta ja siksi ideaalityypin hyöty on käyttää sitä vertailutyökaluna ja sen kautta tehdä todellisuus ymmärrettäväksi (Vartola 1979, 88; Giddens \& Merton 1987, 81; Ahonen 1989, 48). Vartolan (1979, 88) mukaan hallintoa ei voida selittää ymmärtämättä sitä ja ymmärtäminen saavutetaan vasta käsittämällä hallinnon toiminnan merkitys. Ideaalityypit ovat malleja toiminnasta, hal- 
lintatavasta tai kehityskuluista sellaisina kuin toimijat ne itse ymmärtäisivät, jos mallitettavat kohteet voitaisiin puhdistaa kaikista satunnaisuuksista (Ahonen 1989, 48).

Maaseutuhallinnon toiminnan vertailun viitekehyksenä käytetään tässä tutkimuksessa Weberin määrittelemien byrokratian ideaalimallin erikoisominaisuuksia. Ne ovat täsmällisyys, nopeus, selkeys, tietoisuus menneestä kehityksestä, jatkuvuus, harkintavalta, yhtenäisyys, tiukka alisteisuus ja kitkatekijöiden sekä materiaali- ja henkilökustannusten vähentyminen (Weber 1978b, 973, ks. myös Merton 1968, 250; Morgan 2006, 17).

Tämän tutkimuksen kannalta huomio kiinnittyy myös Weberin $(1978,24)$ byrokratiateoriassaan määrittelemiin päämäärä- ja arvorationaaliseen sosiaaliseen toimintaan, joille tunteilla latautunut ja perinteinen toiminta kuitenkin muodostavat rajoja (Ahonen 1989, 52). Päämäärärationaalisuus on välineellistä rationaalisuutta ja siinä keinot ovat tärkeämpiä kuin tavoitteet. Keinoista tulee itseisarvo, joka ei huomioi mitään arvoväitteitä. Arvorationaalisuus punnitsee sekä keinojen että päämäärien roolia. Siinä keinot ovat alisteisia tavoitteille, joita arvioidaan erilaisin kriteerein, kuten arvot, etiikka, estetiikka ja itsenäisesti menestymisen mahdollisuus. (Weber 1978, 25-26.) Jo Weber oli huolissaan byrokratisoitumisen määrän kasvusta ja rationalisoitumisen luonteesta. Organisaatio, joka kiinnittää korostetusti huomiota vain välineelliseen rationaalisuuteen ja väheksyy sisällöllistä rationaalisuutta, ajautuu tilaan, jota Weber luonnehti rautahäkiksi (iron cage). Tässä tilassa keinot ja menetelmät alkavat hallita organisaatiota enemmän kuin tavoitteet. Rautahäkki tekee organisaatiosta vähitellen epäinhimillisen ja muuttaa ihmiset organisaation rattaiksi. (Morgan 2006, 295; Harisalo 2008, 129.)

\section{Byrokratian dysfunktionaaliset ominaisuudet}

Rakenneteoreetikko Robert K. Merton (1968, 251) tunnisti Weberin byrokratiateorian ylivoimaisuuden toimintojen organisoimisessa, mutta tunnisti samalla tutkimuksissaan myös byrokratian ennakoimattomia seurauksia ja piileviä tarkoituksia, mitä hän nimitti byrokratian dysfunktioiksi eli ei-toivotuiksi seurauksiksi.
Merton $(1968,251)$ johdattelee byrokratian negatiivisiin piirteisiin käsitteillä "koulutettu työkyvyttömyys", "ammatillinen psykoosi" ja "ammatillinen muodonmuutos".

Rakenneteoreetikot ovat tunnistaneet sääntöjä, rationaalisuutta, johtamista, persoonallisuutta ja yhteiskuntaa koskevia ei-toivottuja seurauksia (Harisalo 2008, 133-138). Byrokratian dysfunktionalisuutta voi aiheuttaa ensinnäkin sääntöjen tiukka noudattaminen. Säännöt, jotka on alun perin suunniteltu välineeksi, muuttuvat itseisarvoksi, jolloin sääntöjen noudattamisesta itsessään tulee tavoite. Tämä johtaa lopulta kanssakäymisen asiakkaan kanssa mahdottomaksi. Toisaalta sääntöjen tiukka noudattaminen ei mahdollista muuttuneiden olosuhteiden ja asioiden erityispiirteiden huomioimista, jolloin säännöt muodostuvat rationaalisen toiminnan esteeksi. Säännöt ovat voineet jäädä ajastaan jälkeen tai eivät ole muutoin sopivia toimintaympäristöön. Tämä häiritsee lopulta organisaation tavoitteiden saavuttamista ja tällöin esille nousee myös ilmiö virkamiehen teknisyydestä ja paperisota-byrokratiasta. (Merton 1968, 253254.)

Rationaalisuutta koskevia ei-toivottuja seurauksia on tavoitteiden ja keinojen tärkeysjärjestyksen muuttuminen, tavoitteista tulee keinoja ja keinoista tavoitteita (Merton 1968, 253). Organisaatioiden kasvaessa ja onnistuessaan tehtävissään, johtajat voivat kiinnittää yhä enemmän huomiota organisaatioiden ylläpitämiseen, eikä tehtävien toteuttamiseen. Organisaatioilla voi myös olla virallisten tavoitteiden lisäksi piilotavoitteita, joiden saavuttamiseksi ne uhraavat voimavarojaan ja täten heikentävät organisaation rationaalisuutta ja tehokkuutta. (Harisalo 2008, 134.)

Johtamisen osalta ei-toivottuja seurauksia voi aiheuttaa se, että johtajat saattavat olla yhtä sidottuja hallinnollisiin rakenteisiin ja niiden vaatimuksiin kuin heidän työntekijänsä, jolloin rakenteet rajoittavat ja estävät johtajia toimimasta tavoitteellisesti. Toisaalta ihmiset ovat sitoutuneet yllättävän voimakkaasti organisaatioonsa ja muutokset johtamistilanteissa voivat johtaa vastarintaan tai jännitteisiin. Organisaatiot ovat kyvyttömiä korjaamaan virheitään, joiden ei-toivotut vaikutukset ovat olennainen osa organisaation tasapainoa ylläpitävää järjestelmää. (Harisalo 2008, 135.) 
Persoonallisuutta koskevat ei-toivotut seuraukset ilmenevät ensinnäkin asiakkaan persoonattomana kohteluna silloin kun asiakas odottaisi henkilökohtaista palvelua. Tällöin viranomaisesta syntyy ylimielinen kuva, vaikka heidän tulisi olla kansalaisten palvelijoita. Toinen persoonaan liittyvä ei-toivottu seuraus byrokraattisissa organisaatioissa on ihmisten luonnollinen halu vastustaa muutoksia ja halu vakioida omat tehtävänsä mahdollisimman tarkoin. Tällöin organisaatio voi pahimmillaan tehdä ihmisistä tehottomia, haluttomia ja voimattomia. (Merton 1968, 258; Harisalo 2008, 136.)

Yhteiskuntaa koskevia byrokratian ei-toivottuja seurauksia on tunnistettu byrokratian lisääntymisen myötä. Sääntelyn kasvun myötä osaamisvaatimus kasvaa, mikä johtaa asiantuntijavallan vahvistumiseen ja poliittisen vallan vähenemiseen. Vaadittavan tiedon määrän ollessa niin suuri ja yksityiskohtainen, poliitikot eivät pysty sitä hallitsemaan. Tällöin byrokratia autonomisoituu ja alkaa elää omaa elämäänsä. (Vartola 1979, 149; Smith 1988, 44.)

\section{Byrokraattisen hallinnon ja byrokraattisuuden suhde}

Byrokratian on Salmisen (2004, 41, 224) mukaan toimittava demokraattisessa yhteiskunnassa palvelijana, mutta ongelmana on muun muassa hallinnon byrokraattisuus ja hallinnon kasvu. Maaseutuhallinnon kannalta byrokratian lisääntyminen koettiin kansallisesti Suomen liittyessä Euroopan unioniin 1995. Maaseutuohjelman arviointiraportissa vuodelta 2008 (Kuhmonen, ym. 2009) todetaan, että ohjelmassa on paljon "oikeita" asioita, mutta Euroopan komissio ohjaa jäsenvaltiot toimijoineen näkemään maaseudun kehittämisen ensisijaisesti hallintobyrokratian ja hallinnoinnin näkökulmasta. Uusitalo (2009a) korostaa, että säädöksillä pyritään saamaan aikaan tietty yhteiskunnallinen tavoite, mikä on unohtunut monien virkamiesten toiminnassa, kun virkamiehet tulkitsevat asioita säädösten mukaisesti oikeiksi tai vääriksi. Lisäksi säädöksissä ja niiden tulkinnoissa on unohtunut ohjelma- ja hanketoiminnan ydin, harkinnanvaraisuus (Uusitalo 2009b).

Stenvall ym. $(2016,51)$ erottavat byrokratian määrän kasvun kipukohtana Suomessa hyvinvointivaltion kauden rakentamisen ajan 1960-
1980 luvuilla. Silloisia ohjaus- ja suunnittelujärjestelmien perusteita pidettiin byrokraattisina ja niiden nähtiin johtavan hallinnon tehottomaan toimintaan. Uuden julkisen johtamisen kauden myötä 1990-luvulla tavoitteena oli toiminnan tuloksellisuus, tuottavuus sekä niiden arviointi ja mittaaminen, muun muassa sääntelyä purkamalla. Uusi julkinen johtaminen korostaa kansalaista erityisesti asiakkaana ja palvelun käyttäjänä, mutta myös palveluiden rahoittajana, jonka pitää saada vastinetta rahoilleen. Kehittämisen trendi 2000-luvulla on uusi julkinen hallinta, mikä korostaa yhteistyön lisääntymistä yksityisen ja kolmannen sektorin sekä kansalaisten ja eri sidosryhmien kautta. (Stenvall ym. 2016, 51-58.) Viinamäki ym. $(2013,75)$ eivät tunnista vertailututkimuksessaan Suomen, Ruotsin ja Itävallan maaseutuhallinnon toiminnasta uuden julkisjohtamisen tunnusmerkkejä, sen sijaan Hollannin, Irlannin ja Tanskan maaseutuhallinnon toiminnassa uuden julkisjohtamisen periaatteet ovat tunnistettavissa.

\section{AINEISTO JA MENETELMÄ}

Tutkimusaineisto koostuu tekemästäni 38 puolistrukturoidusta teemahaastattelusta. Haastateltavat valittiin oletuksella, että henkilöt tietävät yritystukiprosessin käytännöistä mahdollisimman paljon tai heillä on kokemusta asiasta (Tuomi \& Sarajärvi 2009). Tein haastattelut maaseutu-kaupunki-luokituksen (Suomen Ympäristökeskus 2018) perusteella erilaisiksi tunnistamallani neljällä ELY-keskuksen toimialueella, Etelä-Pohjanmaa, Häme, Lappi ja Pohjois-Karjala, niin että ne edustivat erilaisuudessaan mahdollisimman tasapainoisesti kaupunkien läheistä maaseutua, ydinmaaseutua ja harvaan asuttua maaseutua. Lisäksi haastattelin keskeisiä maaseutuhallinnon toimijoita valtakunnan tasolla.

Maa- ja metsätalousministeriön ja Maaseutuviraston osalta haastattelin johto- ja asiantuntijatason viranhaltijoita. ELY-keskusten haastatellut henkilöt olivat rahoitusasiantuntijoita, maksatuspäälliköitä ja maaseutu- ja energiayksikön päälliköitä. Jokaisella ELY-keskusalueella haastattelin yhtä Leader-ryhmän toiminnanjohtajaa, yhtä kunnan viranhaltijaa sekä kolmea maaseutuohjelman mukaista yritystoiminnan tukea saanutta yrittäjää. Yrittäjät toimivat muun 
Taulukko 1. Tutkimuksessa haastatellut

\begin{tabular}{|l|c|}
\hline Haastatellut & Lukumäärä \\
\hline Norminantaja: & 2 \\
Kansanedustaja & 4 \\
Maa- ja metsätalousministeriön viranhaltija & 3 \\
Maaseutuviraston viranhaltija & 6 \\
\hline Päätöksentekijä: & \\
ELY-keskuksen viranhaltija & 2 \\
\hline Neuvonantaja: & 2 \\
Kuntien yhteistoiminta-alueen viranhaltija & 4 \\
Kuntien elinkeinoyhtiön viranhaltija & 12 \\
\hline Leader-toimintaryhmän toiminnanjohtaja & \\
\hline Asiakas: & 3 \\
Maaseutuohjelman mukaista yritystukea saanut yrittäjä & 38 \\
\hline Arvioitsija: & \\
\hline Manner-Suomen maaseudun kehittämisohjelman arvioitsija & \\
\hline Yhteensä & \\
\hline
\end{tabular}

muassa matkailu-, elintarvikkeiden valmistusja palvelualoilla. Moni haastateltava viittasi lopullisen päätöksenteon kansallisesti olevan kansanedustajilla lakien ja asetusten hyväksymisen kautta, joten lumipalloefektin tavoin otin haastateltaviin mukaan eduskunnan maa- ja metsätalousvaliokunnan jäseniä. Haastateltavat koostuivat siten Suomen koko maaseutuhallinnon ketjun toimijoista, yrittäjästä lainsäätäjään, jolloin sain runsaan ja moniäänisen haastatteluaineiston.

Jaoin haastatellut henkilöt viiteen ryhmään tehtäväkuvan mukaisesti (Pietikäinen \& Mäntynen 2009, 34) (ks. taulukko 1). Norminantajaryhmään lukeutuvat maa- ja metsätalousministeriön ja Maaseutuviraston viranhaltijat sekä kansanedustajat, päätöksentekijä-ryhmän muodostavat ELY-keskusten viranhaltijat, neuvonantaja-ryhmän muodostavat kuntien yhteistoiminta-alueiden ja elinkeinoyhtiöiden viranhaltijat sekä Leader-ryhmien toiminnanjohtajat. Asiakas-ryhmän muodostavat maaseutuohjelman mukaista yritystukea saaneet yrittäjät ja arvioitsija-ryhmään Manner-Suomen maaseudun kehittämisohjelmien arviointia tehneet tutkijat.

Tein haastattelut vuoden 2016 maalis-syyskuun aikana yritysten tai organisaatioiden omissa tiloissa, kolme haastattelua tein puhelimitse haastateltavan oman tiiviin aikataulun vuoksi ja yksi haastattelu siirtyi tammikuulle 2017.
Haastattelujen pituudet vaihtelivat 46 minuutista 2 h 5 minuuttiin, haastattelupuhetta kertyi yhteensä 51 tuntia 30 minuuttia. Näkemykseni mukaan aineisto saavutti saturaation jo kolmen alueen haastattelujen aikana, mutta tein haastattelut alkuperäisen tutkimussuunnitelman mukaisesti neljällä alueella Suomessa. Suomen eri alueiden ihmisten puheet olivat rikasta ja vivahteikasta puhetta ja loivat aineistosta arvokkaan ajanhetken kuvaajan. Koin haastattelut tarkoituksenmukaiseksi ja näkökulmia avartavaksi tavaksi kerätä tutkimuksen aineisto.

Haastattelun teemat olivat samat kaikille haastateltaville, mutta eriytin kysymysten näkökulmat paikallis- ja aluetasolle, valtakunnantasolle sekä toimijoittain yrittäjille, arvioitsijoille ja kansanedustajille. Teemoina olivat haastateltavan omat tuntemukset neljännen EU-ohjelmakauden alkaessa, viranomaisen ja yrittäjän motivaation lähteet omassa työssä, maaseudun kehittämisohjelman hallinnolliset kipukohdat, yhteistyö yrittäjän ja viranomaisen välillä, viranomaisen toiminta yrittäjyyden edistämisessä, paikan merkitys yritystoiminnan kannalta sekä arviointitiedon hyödyntäminen omassa työssä. Lähetin haastattelurungon haastateltaville etukäteen tutustuttavaksi. Haastattelut nauhoitettiin ja litteroitiin sanatarkasti yhtä haastattelua lukuun ottamatta, mikä kuitenkin taltioitiin muistiinpanojen muodossa. 


\section{Kriittinen diskurssianalyysi ymmärtämisen välineenä}

Fairclough (2005) painottaa diskurssianalyysin tärkeyttä organisaatioiden tutkimuksessa, koska diskurssianalyysin kriittisten tavoitteiden myötä nousee esille muun muassa kysymykset: miten on mahdollista, etteivät ihmiset tiedosta puheensa sosiaalista luonnetta ja millaisia sosiaalisia vaikutuksia tällä voi olla (Fairclough1995, 36)? Ongelmien tarkastelussa kriittisen diskurssianalyysin kiinnostuksen kohteena on kieli sosiaalisena käytäntönä ja kielenkäytön konteksti ja se antaa mahdollisuuden tarkastella erityisesti näkymättömiä ja näkyviä valta-asetelmia etsien myös keinoja mahdollisten harhakuvitelmien poistamiseen (Wodak 2004, 199). Valtaanalyysissä painotetaan diskurssien välisiä ja sisäisiä valtasuhteita ja analysoidaan sitä, miten tietyt diskurssit muotoutuvat hegemonisiksi sekä pohditaan muutoksen mahdollisuutta (Jokinen ym. 2016, 75). Kriittinen lähestymistapa pitää sisällään poliittisen ja emansipatorisen intressin: yhteiskunnallinen muutos saadaan aikaan kriittisen ymmärryksen ja tietoisuuden kautta (Pietikäinen 2000, 200-201).

Ymmärrän diskurssin tässä tutkimuksessa Wodakin $(2004,199)$ tavoin tiedonmuotona ja sosiaalisen toiminnan käytäntönä. Diskurssi edustaa siten lähinnä yhteiskunnallista ja historiallista makrotasoa, jolloin merkitysten voidaan katsoa olevan diskursiivisen toiminnan tulos. Näen diskurssin myös Alasuutarin (1996, 21) tavoin puheavaruuksina, joita tarkastellaan ajallisesti ja paikallisesti ainutkertaisina merkitysten, käytäntöjen ja toimijoiden asemien muodostumina. Toimijan asemista puhumisen idea on siinä, että kiinnitetään huomiota tapaan, jolla yksittäisen ihmisen paikka määrittyy sosiaalisen ryhmän vuorovaikutuksessa. Millä tahansa hetkellä yksilöllä voi olla hallussaan useita positioita, jotka määrittävät hänen tilannettaan eri tavoin. Selviytymisstrategiat ovat keinoja, joilla ihmiset löytävät omasta toimijan asemastaan mielekkyyttä ja jotka tekevät siihen kuulumisesta jopa nautinnollista. (Alasuutari 2007, 182-194.)

Tein aineiston analyysin teoriaohjautuvasti käyttäen strukturoituna analyysirunkona Weberin (1978b, 973) byrokratian ideaalimallin erikoisominaisuuksia (ks. Tuomi \& Sarajärvi 2009, 113). Analyysin apuna käytin Nvivo-ohjelmaa. Sanahaun avulla selvitin mitä ja miten haastateltavat puhuvat byrokratian ominaisuuksista; täsmällisyys, nopeus, selkeys, asioiden tuntemus, jatkuvuus, harkinta, yhtenäisyys, tiukka alisteisuus, kitkatekijöiden sekä materiaali- ja henkilökustannusten vähentyminen. Haussa käytin myös ominaisuuksien vastakohtia tai muutoin ominaisuuksia selittäviä sanoja; tarkka, hitaus, yksiselitteinen, monimutkainen, osaaminen, kokemus, yhtäjaksoisuus, katkeaminen, kokonaisuus, pirstaleisuus, lisääntyminen, resurssi ja säästö. Ja lopuksi tutkin missä yhteydessä ja miten haastateltavat käyttävät byrokratia-sanaa. Näin kykenin tarkastelemaan byrokratian ominaisuuksia maaseutuhallinnon kontekstissa. Aineisto oli runsas ja yksittäisiä ominaisuuksiin viittaavia seikkoja tuli runsaasti.

Ominaisuuksien tarkastelun jälkeen jatkoin analyysia selvittämällä mitä ja miten haastateltavat puhuvat yrittäjästä asiakkaana ja viranomaisesta viranomaisena. Näin sain muodostettua subjektipositiot päätöksentekijälle ja asiakkaalle. Tavoitteena oli etsiä toimijoiden puhetavoista niissä eläviä yhteisiä merkityksiä eikä tarkastella vain ryhmien erilaisia puhetapoja ja tuottaa toimijakohtaisia diskursseja (ks. Jokinen ym. 2016, 80 ). Haastattelujen ajankohta, kevät 2016, tuotti hyvinkin kriittistä puhetta maaseutuhallinnon toiminnasta EU-ohjelmakauden hitaan käynnistymisen vuoksi. Luin, ryhmittelin ja tiivistin aineistoa byrokratian ideaalimallin erikoisominaisuuksien ja haastateltavien kertomien käytäntöjen avulla.

\section{ARJEN PUHUNTA MAASEUTUHALLINNOSSA}

Analyysitulosten perusteella erotin kolme diskurssia, joiden katsoin vastaavan tutkimuskysymyksiin. Diskurssien sisällä tarkastelin kuinka alueellisten ELY-keskusten yritystukien myöntö- tai maksupäätöksentekijät ja toisaalta asiakkaat eli yritystukia saaneet yrittäjät asemoituvat tunnistetuissa diskursseissa, koska näkemykseni mukaan yritystukiprosessissa päätöksentekotilanne heijastelee koko maaseutuhallinnon ketjun toimintaa, lakien, asetusten ja toimeenpanon sujuvuutta ja ymmärrettävyyttä 
sekä asiakkaan että päätöksentekijän kannalta. Nimesin diskurssit seuraavasti 1) lainkuuliaisuus 2) järjestelmä isäntänä ja 3) kokonaisuus kateissa. Järjestelmä isäntänä -diskurssi oli helposti tulkittavissa haastateltavien puheista. Lainkuuliaisuus -diskurssi oli niin itsestään selvää ja toistui palasina eri toimijoiden puheissa heidän puhuessa arjen käytännöistään, että luin aineiston useaan kertaan ymmärtääkseni puheen merkityksen. Kokonaisuus kateissa -diskurssi oli erotettavissa ja nimettävissä omaksi merkityskokonaisuudekseen. Tutkimuksessa haastateltujen henkilöiden puheessa korostui puhe byrokraattisuudesta, byrokratian dysfunktionaaliset ominaisuudet nousivat dominoiviksi piirteiksi.

\section{Lainkuuliaisuus}

Lainkuuliaisuus-diskurssi kuvastaa erityisesti byrokratiamallin tiukan alisteisuuden erikoisominaisuutta. Lakien ja asetusten asema korostuu toimijoiden puheessa. Niin yrittäjät ja päätöksentekijät kuin normin- ja neuvonantajat sekä arvioitsijat tuottavat puheissaan ja käytännöissään lainkuuliaisuutta. Lainkuuliaisuus on arvo, ajatus- ja toimintatapa. Samalla yritystukien toimeenpano osana maaseutuohjelman kokonaisuutta on rakentunut monimutkaiseksi ja vaikeasti ymmärrettettäväksi ja jopa järjettömäksi kuvatuksi kokonaisuudeksi. Lakien ja asetusten noudattaminen muuntuu byrokratiapuheeksi ja päätyy asiakkaalle ja myös viranomaisille itselleen koituvan hallinnollisen taakan kuvaamiseen. Maaseutuohjelman tavoitteita pidettiin hyvinä, mutta kehittämistyöhön ei koettu jäävän aikaa, koska tukijärjestelmien hallinnoinnin, lakien, asetusten ja määräysten opettelun sekä noudattamisen koettiin vievän kohtuuttomasti aikaa.

"Ja tää byrokratia, mikä tähän tulee, niin se on tavallaan se hinta siitä rahasta, minkä hän meiltä saa.” Päätöksentekijä

"Pitää kertoa, että tämä on niin hölmöä, että tämä tuntuu hölmöltä, mutta tämä pitää tehä näin, niin sillon se pitää tehä näin." Neuvonantaja
Lainkuuliaisuus-diskurssissa päätöksentekijät asemoituvat lakien ja asetusten toimeenpanijoiksi ja lainvartijaksi. Asiakkaat saavat lakien ja toimeenpano-ohjeiden noudattajan aseman. Lainvartija varmistaa lainkuuliaisuuden sekä oman että asiakkaan työn osalta. Asiakkaat työmotivaation antajana ovat osa lainvartijoiden selviytymisstrategiaa, asiakkaiden avulla he sietävät omassa toiminnassa kokemansa byrokraattisuuden, jolloin lainvartijan toiminta rakentuu asiakasystävälliseksi tiedontuottajaksi asiakkaalle. Samalla koetaan oman työn rajoitteet ja kaventuminen tiukkoina pidettyjen asetusten ja määräysten myötä. Päätöksentekijät kertovat, että he eivät voi neuvoa asiakasta siinä määrin kuin haluaisivat eikä harkintavaltaa tukipäätöksissä juurikaan ole. Asiakkaiden puheessa kritiikki kohdistuu ensisijaisesti sääntöjen ja järjestelmän monimutkaisuuteen, asiakaspalvelua tekevät päätöksentekijät merkityksellistyvät yksilöinä asiakkaan palvelijoiksi. Norminantajat korostivat puheessaan päätöksentekijöiden virkavastuuta ja sitä kautta säädösten mukaista toimintaa.

"Oon sitten maatilapuolella tai yrityspuolella niin ne ongelmat, mitä tos oon puhunu, mun mielestä ei oo johtunu näistä henkilöistä, vaan se systeemi on liian jäykkä ja vaikee." Asiakas

"Meitä nyt valvotaan, meitä rajotetaan. Se joustavuus, liikkumavara nopeasti reagoida niihin muutoksiin yrittäjän suuntaan, jotka kumminkin mahdollistais ja yrityksen kannalta helpottas heidän elämää, niin se joustavuus on viety, aika olematon.” Päätöksentekijä

"Ja sitten tietysti viranomaisen pitää antaa kaikki tieto, mitä asiakas tarvitsee. Mut sit pitää muistaa myös, et on viranomainen. Et, jos tulee jotain, kaikki ei suju, niin sitte pitää viranomaisena toimia. Et, ei saa olla, ei ole neuvoja. Että vaikka me puhutaan palveluista, mut ne on viranomaispalveluja ja niihin liittyy virkavastuu. Ja sitten se säädösten mukainen toiminta." Norminantaja

Diskurssi korostaa suomalaisten totuttua tapaa noudattaa sääntöjä. Suomessa sääntöjen noudattaminen on tapa ja toimijat korostavat puheessaan, että EU:n hallintokulttuuri on tehty 
lähtökohtaisesti muunlaiseen hallintokulttuuriin. EU:n hallintokulttuurin koetaan tuoneen ongelmia Suomen maaseutuhallinnon toiminnan sujuvuuteen. Suomalaisen hallintokulttuurin arvo, luottamus, on alistettu EU:n hallintokäytännöille, missä tuensaajaa ensisijaisesti epäillään. Sujumattomuus tiivistyy luottamuksen puutteeseen, mikä tuo mukanaan pyrkimystä virheettömän hallinnon kulttuuriin ja estää hyvän hallinnon kulttuurin toteutumista.

"Meillä on ollu semmonenkin aika ja sellainen luottamuksen ja hyvän hallinnon kulttuuri näissä asioissa joskus olemassa, että ei se mahdotonta ole. Mutta näin monimutkaisella järjestelmällä, jossa on näin paljon ehtoja, niin kyllä sellaisen hyvän hallinnon kulttuurin saavuttaminen on kyllä hirvittävän hankalaa. Että kyllä se edellyttäis melkein sitä, että järjestelytkin olis huomattavasti yksinkertaisemmat." Arvioitsija

\section{Järjestelmä isäntänä}

Järjestelmä isäntänä -diskurssi jäsentyy puheista ohjelmakausien katkoksista, toimeenpanon ja päätöksenteon hitaudesta, valvonnasta ja tarkastustoiminnasta sekä konkreettisesta tukien hallinnoinnin tietojärjestelmästä Hyrrästä. Se sisältää myös puhetta tukijärjestelmien monimutkaisuudesta. Byrokratian ideaalimallin ominaisuudet, jatkuvuus, nopeus ja selkeys ovat vain toiveunta haastateltavien puheissa.

Uuden ohjelmakauden rakenteilla ollut tietojärjestelmä ei valmistunut sille luvatussa aikataulussa, mikä oli tapahtunut myöskin edellisen ohjelmakauden vaihteessa. Myöskään ohjelmakauden toimeenpano-ohjeet eivät olleet selvillä vielä, vaikka ohjelmakautta oli kulunut runsas kaksi vuotta. Viive aiheutti katkoksia yrittäjien investointeihin ja kehittämistoimiin ja hidasti ja hankaloitti myös viranomaisten toimintaa. Puheen Hyrrästä useimmat olisivat halunneet lähes ohittaa kuittaamalla, mutta eivät silti tehneet sitä, koska tietojärjestelmä oli niin merkittävä tekijä asioiden sujumisen kannalta. Ohjelmakauden vaihdos koettiin epäonnistuneeksi. Tukijärjestelmien yksinkertaistamisen tavoitteet eivät olleet arvioitsijoiden, päätöksentekijöiden, asiakkaiden eivätkä myöskään normin- ja neuvonantajien mielestä toteutuneet.
"Jos ne ATK-järjestelmät jättää omaan arvoonsa niin, no se ensinnäkin teettää meille hirvittävästi turhaa työtä, kun me tehdään ne nyt manuaalisesti. Sit me joudutaan viemään ne jälkikäteen järjestelmään --- mut, tää laaja-alasuus on semmonen kipukohta --- meillä on ensinnäkin se ohjelma-asiakirja, luo oikeutuksen tukeen. Meillä on maaseutualueiden ryhmäpoikkeusasetus, meillä on yleinen ryhmäpoikkeusasetus, meillä on de minimis-asetus, meillä on neljät valtiontukisäädökset, minkä pohjalta me tukea myönnetään. No sitte se jakautuu...” Päätöksentekijä

"Mutta jos ei nyt puhuta Hyrrästä, niin kun ei saada tätä tietoteknistä toteutusta. Mutta vielä suurempana mä pidän sitä, että ei saada selviä sääntöjä siitä, mitä rahoitetaan, kuinka rahoitetaan. Se on niin kuin vielä käsittämättömämpää." Neuvonantaja

Päätöksentekijä asemoituu järjestelmä isäntänä -diskurssissa järjestelmän toimeenpanijaksi. Diskurssi asemoi yrittäjän toiminnan kohteeksi. Haastatellut yrittäjät olivat saaneet yritystoiminnan tukea vähintään kerran aikaisempien ohjelmakausien aikana ja monella oli hakemus vireillä haastatteluhetkellä. Tukien hakuprosessi tunnistettiin yleisesti hankalaksi ja vaikeaksi. Asiakkaat kertoivat tukihakemusten täyttämisen apuna olleen ulkopuolinen neuvojataho ja maksatushakemusten täyttämisessä oman yrityksen kirjanpitoa pitävä tilitoimisto. Diskurssi sisältää myös yrittäjien vastapuhetta kohteena olemisesta. Jotkut yrittäjistä olivat tiedostaneet ja hyväksyneet tukijärjestelmien vaatimukset ja ohjeita noudattamalla pystyivät itse täyttämään tarvittavat hakemusasiakirjat sekä myös halusivat kannustaa yrittäjäkollegoitaan tukien hakemiseen.

"Siis osa vaan sanoi, että ei viitti täyttää papereita ja kokee sen vaikeeksi ja näin. Katin kontit. Siis ei se ole, apuahan voi pyytää, jos ei niitä koe itse pystyvänsä täyttämään.” Asiakas

Tukien myönnön ja maksatuksen tehtävien eriyttäminen kerrottiin kasvattaneen päätöksentekijän arjen hallinnollista taakkaa. 
"Sillä tavalla tää eriyttäminen tuli ja sehän toi sitte hankaluuksia kaikkien tekemiseen, kun pienellä porukalla tekee, niin yhtäkkiä ei ollukaan niitä tekijöitä joka lisaukseen sitte uutta. Se tässä on muuttunu." Päätöksentekijä

Myös tarkastuslistojen mukaisesti tehtävät maksatustarkastukset korostuvat sekä päätöksentekijöiden että asiakkaiden puheissa. Tarkastuksista eli valvonnoista on rakentunut osa yrittäjän arkea ja merkittävä osa päätöksentekijän työtä. Tarkastusten kautta yrittäjä todistaa tehneensä yritystukihakemuksen päätöksen mukaiset toimet ja hakeneensa maksatusta vain tukiin oikeuttaville toimille. Vaikka tarkastukset ymmärretään tarpeellisiksi väärinkäytösten estämisen kannalta, niitä kuvataan puheissa liian yksityiskohtaisiksi. Puheet tarkastuksesta sisältävät sellaisia sanoja kuin nippeliasioiden tarkastus ja pilkunviilaus. Yrittäjän arjessa kirjalliset lisäpyyntöselvitykset rakentuvat toiminnan tehottomuudeksi.

"Katsotaan kirjanpidot, siis ihan tositteittain. Pyydetään tarvittaessa lisätiedot, esimerkiks tuntikirjanpidot ja jotakin lisäselvityksiä. Sitten katsotaan maksutositteet. Loppumaksuyhteydessä tehdään hallinnollinen tarkastuskäynti, jossa todetaan, että se hanke on toteutettu, ja sitten käydään tilitoimistossa tai sillä yrittäjällä itsellään, jossa kirjanpito on, niin katsotaan niitä tositteita, että ne on samanlaiset kuin, mitä meille on toimitettu ja sitten laitetaan maksuun." Päätöksentekijä

"Joo, niin että tervettä maalaisjärkeä ois minusta kyllä tarvittu, summat on noin mitättömiä, pieniä. Mutta, sitte pyydetään kirjallinen selvitys siitä 45 sentistä, nii. Minun raja kulki siinä." Asiakas

"Kun lähtökohtahan on se että, yritystukien osalla kaikki on lähtökohtaisesti kiellettyä, ellei se oo erikseen sallittua." Päätöksentekijä

\section{Kokonaisuus kateissa}

Kokonaisuus kateissa -diskurssi sisältää puhetta menneestä kehityksestä, yhtenäisyydestä ja kitkatekijöistä. Se sivuaa materiaali- ja henkilökustannuksia. Osaaminen ja kokemus raken- tuvat haastateltavien puheessa tärkeäksi ominaisuudeksi erityisesti norminantajalle. Yksilöominaisuudet korostuivat uusien norminantajien osalta, sillä vähäisen käytännön kokemuksen koettiin tuottavan tarpeettoman tiukkaa toimeenpanon ohjeistusta, pyrkimyksenä jälleen rakentaa virheettömän hallinnon kulttuuria.

"Ni siellähän on niin kokemattomia ne ihmiset, jotka tekee näitä ohjeistuksia, että ei niillä oo käytännön kokemuksesta mitään käsitystä, ja ne tekevät niitä ohjeistuksia, ja ne ohjeistukset ovat sitten tarkempia ku se laki ja asetus." Neuvonantaja

"Tietysti kaikki nää valvonta ja maksatus se nyt tulee EU:sta, mut se miten ne toimeenpannaan ja mitä kansallisia helpotuksia siihen voi olla olemassa niin kyllähän siel on. On ollu aikasemmin ja on edelleen, mut niit ei välttämättä haluta ottaa käyttöön vaan, halutaan toimii niin että viranomainen ei itse tekis virhettä." Norminantaja

Päätöksentekijät asemoituvat diskurssissa lainsäädännön sekä tukiehtojen tulkeiksi ja sitä myöten tiedonvälittäjiksi. Asiakkaat rakentuvat tiedon vastaanottajiksi. Päätöksentekijöiltä vaaditaan mittavan ja vaikeaselkoisen lainsäädännön tuntemusta sekä tukiprosessin kokonaisuuden ymmärtämistä, mikä korostuu heidän puheessa. Norminantajan koettiin voivan keskittyä usein hyvinkin yksityiskohtaiseen osaan tukiprosessista. Asiakkaille oli osittain rakentunut pelko siitä, että tietävätkö he kuitenkaan, mitä kaikkia lakeja tulisi noudattaa.

"Ja se että, kuitenkin suurimmalle osalle rahoitusasiantuntijoista on aika haasteellista hallita se sitova ja velvottava lainsäädäntö ja sen tulkinnat. Ja puhumattakaan siitä että, pysyä kärryillä, kun yhtälailla komission lainsäädäntö elää ja muuttuu." Päätöksentekijä

"No, ELY:t on joutunu siitä syystä ohjeistamaan asiakkaita, ehkä kansanomaisemmin yksinkertasemmin, ja sitten jalkauttamaan sen ohjeistuksen sinne alueelle." Päätöksentekijä

Kokonaisuus kateissa -diskurssissa vuorovaikutus rakentuu yksisuuntaiseksi, ylhäl̈lä alaspäin 
suuntautuvaksi. Tuntemukset neuvonantajien ja päätöksentekijöiden paikallis- ja aluetason kokemuksen ja osaamisen ohittamisesta rakentuvat puheessa yhteistyötä hidastavaksi piirteeksi ja erityisesti haittatekijäksi uuden ohjelmakauteen liittyvien käytäntöjen luomisessa. Kitkaa aiheutui myös norminantajien välisistä asetusten tulkintaristiriidoista ja myöskin ohjelman toteuttamisen tavoista, jolloin asiantuntemuskin kyseenalaistui. Kokonaisuuden koettiin olevan kateissa, mikä tuotti alue- ja paikallistasolle viivettä ja hämmennystä erityisesti ohjelmakauden vaihteessa.

"Se on just se oleellisin ongelma nyt, että meillekin ne sanelee sieltä uusia määräyksiä ja muuta, jotka hämmentää koko kenttää --- ei oo kuunneltu toimijoita, jotka on ollu jo paljon pidempään kentällä ja joilla on käytännön kokemusta. Niin tehdään niitä samoja virheitä, jotka on jo tehty 1900-luvulla." Neuvonantaja

Kokonaisuus kateissa -diskurssi ilmentyy myös puheessa oman työn motivaation lähteistä. Maaseutuohjelman koettiin muodostuneen neljän ohjelmakauden myötä rahoituksenjako-ohjelmaksi ilman selviä tavoitteita, minkä erityisesti päätöksentekijät kertoivat heikentävän oman työn motivaatiota. Ohjelmakausittain vaihtuviin toimenpiteisiin kaivattiin jatkuvuutta ja pitkäjänteisyyttä. Toimeenpanoon peräänkuulutettiin laaja-alaista kehittämisotteen mahdollisuutta ja maaseudun ympärillä olevan yhteiskunnan kehityksen kokonaisuuden huomioimista. Puheet tavoitteista, rahoituksen määrästä ja yksinkertaistamisen vaatimuksista tuottivat ristiriitaista puhetta norminantajien keskuudessa.

"Ku meiltä oikeestaan puuttuu ne kehittämisohjelmat elikkä sisältöjen tavotteellinen ajattelu sieltä sisältä. Eli nää on tälläsiä, rahotusripustustelineitä nää ohjelmat, koska siel on kaikkee kaikille." Norminantaja

"Elikkä, nythän hirveesti puhutaan täst yksinkertastamisesta, mutta mun mielestä pitäis koko ajan miettiä, et saadaanko, onnistutaanko yhtä hyvin, kun nyt tän EU-rahotuksen saamisessa. Se ois aivan ydinjuttu. Koska, jos me saadaan rahaa, niin kyllä me sitten, sen tuella tätä maaseutuu kehitetään.” Norminantaja

\section{POHDINTA}

Tämän tutkimuksen haastattelujen teko ajoittui Suomen EU-ohjelmakausien neljännen ohjelmakauden alkuun eli kolmanteen vaihdokseen. Uutta ohjelmakautta oli eletty reilu kaksi vuotta, mutta puutteellisten ohjeiden ja tietojärjestelmien vuoksi muun muassa yritystukipäätöksiä ei ollut voitu vielä tehdä. Kriittinen turhauma yhteisen maatalouspolitiikan (CAP) toimeenpanon hitautta ja koko maatalouden heikkoa kannattavuutta kohtaan oli kulminoitunut viljelijöiden traktorimarssiin Helsingin Senaatintorille ja byrokratiapyykkinaru oli ollut myös nähtävillä Euroopan parlamentissa. Haastateltavat arvioivat, että taloudellinen taantuma rauhoitti yritystukia hakeneiden yrittäjien nousemista barrikadeille, koska hakijoita oli vähän suhteessa viljelijätukia hakeneisiin.

Tutkimuksessa tunnistetut diskurssit kietoutuvat toisiinsa. Lainkuuliaisuus toistuu toimijoiden puheessa ja muotoutuu hegemoniseksi diskurssiksi. Lakia ja asetuksia noudatetaan ehdoitta, mikä on osa suomalaista yhteiskuntaa. Lainkuuliaisuus-diskurssissa kuitenkin sääntelyn noudattaminen muuttuu osittain itseisarvoksi, jolloin sääntöjen noudattaminen on ensisijaista ja siten häiritsee organisaation tavoitteiden saavuttamista. Tämän prosessin äärimmäinen tuote on Mertonin $(1968,254)$ kuvailema byrokraattinen virtuoosi, joka ei koskaan unohda yksittäistä sääntöä, tai pysty sitä soveltamaan tilanteen edellyttämällä tavalla ja näin hän lopulta menettää kyvyn palvella asiakastaan. Alueellinen päätöksentekijä on kuitenkin tutkimuksen tulosten mukaan vielä säilyttänyt kyvyn palvella asiakasta, asemoituen diskurssissa siltikin lainvartijaksi ja tukien toimeenpanijaksi. Asiakas rakentuu ohjeiden noudattajaksi. Lainkuuliaisuus-diskurssi tarjoaa mahdollisuuden vastuun ulkoistamiseen. Lakiin vetoamalla päätöksentekijä voi ottaa etäisyyttä asiakkaaseensa ja vierittää vastuun päätöksenteon ongelmista norminlaatijalle, joka taas voi puolestaan kätkeytyä EU-lainsäädännön taakse.

Järjestelmä isäntänä -diskurssissa puheet maaseudun elinvoimasta ja yrittäjyydestä kietoutuvat yhteen Hyrrän toimivuudesta, valintakriteereistä ja tarkastuslistoista. Diskurssi on pääosin rakentunut Suomen EU-aikakauden aikana ja korostuu ohjelmakauden vaihteessa, 
mutta ilmenee jatkuvana haastateltavien puheessa. Tieto- ja tukijärjestelmät ohjaavat arjen tekemistä. Byrokratian ei-toivottuja seurauksia aiheuttaa asiakkaan persoonaton kohtelu (Merton 1968, 254) päätöksentekijän asemoituessa toimeenpanijaksi ja asiakkaan asemoituminen erityisesti valvonnan kohteeksi. Diskurssi kuvastaa Salmen (2003) tutkimuksen löydöstä siitä, että TE-keskusten henkilöstö koki olevansa kumileimaisia päätöstä tehdessään tarkistaen vain, että hankkeet täyttivät erilaiset säännöt ja määräykset. Harkintavaltaa ei päätöksenteossa juurikaan koettu olevan, valta koettiin olevan norminantajalla.

Kokonaisuus kateissa -diskurssi korostaa tukijärjestelmän monimutkaistumista niin, että se on vain harvojen, ehkä ei kenenkään hallussa, kuten myös Salmi (2003) on todennut tutkimuksessaan. Diskurssi heijastaa byrokratian ei-toivottuja seurauksia yhteiskunnan ja johtamisen osalta. Tukijärjestelmiin liittyvä tieto on niin yksityiskohtaista, että asiantuntijavalta on dominoivaa suhteessa poliittisen päättäjän valtaan (vrt. Smith 1988, 44). Järjestelmän monimutkaisuus tekee ihmisistä tehottomia ja voimattomia, kuten Merton $(1968,258)$ on todennut organisaation vaikutuksesta. Ohjelmakaudet ovat määräaikaisia, jolloin ohjelmakausista muodostuu irrallinen kokonaisuus, kun ei ole muodostettu riittävää kansallista strategista tahtotilaa ja visiota maaseudun kehittämisen suunnasta. Yhteisen strategisen suunnan puuttuminen lisää kitkaa toimijoiden keskuudessa. Kokonaisuus kateissa -diskurssissa myös keinoista tulee tavoitteita, kun maaseutuohjelman onnistumista mitataan rahan käytöllä. Alueellinen päätöksentekijä pyrkii diskurssissa tunnistamaan asiakkaan tarpeet rakentuen yritystukiprosessin tiedonvälittäjäksi

Diskurssien sisällä toimijoiden valtataistelu on vähäistä, koska valta kulminoituu norminantajalle. Diskursseissa korostuu päämäärä- eli välineellinen rationaalisuus, byrokratian dysfunktionaaliset ominaisuudet jättävät ideaalimallin ominaisuudet taka-alalle. Viranomaiset pyrkivät toiminnassaan kunnioittamaan valtionhallinnon arvoja, mutta järjestelmän monimutkaisuus ja vaikeaselkoisuus ei mahdollista arvojen toteutumista käytännössä. Erityisesti avoimuus ja luotettavuus kyseenalaistuvat hitauden ja viiveiden ansiosta. Rationaalisuuden perusteella diskurssit yhdistyvät yhdeksi suureksi diskurssiksi, mikä voidaan nimetä maaseutuhallinnon byrokratian rautahäkiksi. Seuraava sitaatti kuvaa tätä diskurssien solmua:

\begin{abstract}
"Kun täs puhutaan just näistä, kysymyshän lähti tästä yritystukien rahoituksesta ja muusta niin tää, tietyllä tavalla ilmentyy just tässä, että kun on tuo historia ja kontrollitarve. Ja juuri, et niistä epäonnistumisista, takaisinmaksuista ja muista tehdään aika iso numero, ja pelote. Niin kyllä se on omiaan sitten myöskin, jäykistämään sitä ja palataan ikään kuin mielellään siihen varmaan tekemiseen. Ei haluta näitä epävarmuuksia missään tapauksessa mukaan." Arvioitsija
\end{abstract}

Byrokratian rautahäkissä keinoista ja välineistä tulee itseisarvo. Maaseutuohjelman elinvoimaisen maaseudun ja monipuolisen yrittämisen tavoitteet hukkuvat lakien, asetusten ja määräysten toteuttamisen alle. Päämäärärationaalinen puhunta on niin hegemonista, että byrokratiapuhunnasta on kadonnut arvorationaalinen ulottuvuus. Byrokratia näyttäytyy maaseutuhallinnossa autonomisena itsevaltiaana. Vihisen (2014) mukaan Euroopan unionin yhteistä maatalouspolitiikkaa on pyritty uudistamaan useita kertoja 1980-luvun lopulta lähtien, mutta uudistukset ovat tapahtuneet hyvin hitaasti ja matalalla profiililla. Vihinen (2014) arvioi, että hallinnolla on oma intressinsä nykyisenkaltaisessa, monimutkaisessa ja laajassa maatalouspolitiikassa, sillä sen voi katsoa takaavan heidän valta-asemiaan isojen resurssien ja monimutkaisen sääntelyn hallitsijoina.

Tämän tutkimuksen tulosten perusteella maaseutuhallinnon arjen puhunnassa ilmeneviä byrokratian ei-toivottuja seurauksia voidaan byrokratian ideaalimallin ominaisuuksien kehikon avulla kuvailla seuraavasti. Toimeenpano on tarkkaa sekä ohjeiden että valvonnan osalta. Päätöksenteko on hidasta, asiat ovat monimutkaisia, vaikeasti ymmärrettäviä. Viranomaistoimijat kyseenalaistavat toistensa osaamista ja kokemuksia ei kuunnella. Jatkuvuutta ei ole, koska ohjelmakaudet tuovat katkoksia tukijärjestelmiin. Yksittäisen viranomaisen harkintavalta on kaventunut päätöksenteossa, mutta toisaalta norminantajalla on liiaksikin valtaa säädösten 
ja ohjeiden valmistelussa. Kaikki toimijat noudattavat lakeja ja asetuksia. Kitkatekijöitä aiheuttavat toimijoiden väliset ristiriidat lakien ja asetusten tulkinnoista. Materiaali- ja henkilökustannuksia on vähennetty valtiontalouden säästökuurien leikkauksilla, mutta tukihallinnon kustannuksia ei seurata kokonaisuutena, joten byrokratian hinta on arvailua. Sääntelyn noudattaminen sitoo henkilöresursseja kehittämisen kustannuksella.

Byrokratian rautahäkkiä ja dysfunktionaalisia ominaisuuksia todentaa myös Valtiontalouden tarkastusviraston (2013) lausunto, että EU:n yhdennetyn hallinto- ja valvontajärjestelmän hyödyt ja haitat Suomessa ovat epätasapainossa. Järjestelmä takaa tukihallinnon laillisuuden, mutta jättää liian vähälle huomiolle aikaansaatavat hyödyt ja hallinnosta aiheutuvat kustannukset. Valtiontalouden tarkastusviraston (2013) lausunnossa todetaan, että merkittäviin rahoitusoikaisuihin johtaneita virheitä ei ole ollut. Tältä osin järjestelmä toimii hyvin.

Tutkimuksessa haastatellut henkilöt olivat motivoituneita haastateltaviksi ja valmiita avoimeen keskusteluun haastattelutilanteessa. Haastattelujen aikana byrokratia oli esillä eri medioissa, joten maaseutuhallinnon byrokratian ominaisuksia olisi voitu tutkia esimerkiksi lehtileikkeiden tai sähköisten aineistojen kautta. Henkilökohtainen puhe toimijoiden kanssa tuotti kuitenkin arvokkaan ja rikkaan tutkimusaineiston. Tutkimuksessa ei haastateltu EU-tason toimijoita, mitä voidaan pitää yhtenä tutkimuksen rajoitteena. EU-tason ja norminantajien suhteen tarkastelu voisi olla uuden tutkimuksen aihe. Tutkimuksessa ei myöskään juurikaan tarkasteltu johtajuuden merkitystä byrokratian ilmiöön maaseutuhallinnossa, vaikkakin johtajalla on aina merkittävä vaikutus organisaatioiden toimintatapojen muodostumiseen, tässä tapauksessa byrokraattisuuden määrään. Tämä voisi olla myös uuden tutkimuksen aihe. Diskurssianalyysi pyrkii kuvaamaan tutkittavan ilmiön sosiaalista todellisuutta, mutta diskurssit ovat aina tutkijan tulkitsemia. Tutkimuksen luotettavuutta olen pyrkinyt varmistamaan runsaalla tutkimusaineistolla ja huolellisella aineiston analyysilla.

\section{JOHTOPÄÄTÖKSET}

Tässä artikkelissa tarkasteltiin, millaisia byrokratiaa kuvaavia diskursseja rakentuu maaseutuhallinnon toimijoiden puheessa EU-osarahoitteisen maaseudun kehittämisohjelman yritystukien valmistelun ja toimeenpanon yhteydessä. Tutkimuksessa tunnistetut kolme diskurssia, lainkuuliaisuus, järjestelmä isäntänä ja kokonaisuus kateissa heijastavat byrokratian dysfunktionaalisia ominaisuuksia jättäen Max Weberin kehittämän byrokratian ideaalimallin erikoisominaisuudet varjoonsa. Tutkimuksen tulosten mukaan byrokratian ei-toivotut seuraukset ovat kasvaneet maaseutuhallinnon arjen todellisuudessa byrokratian ideaalimallin ominaisuuksia dominoivaksi.

Tämän tutkimuksen tulosten mukaan maaseutuohjelman tukijärjestelmän monimutkaisuus ja yksityiskohtaisuus tuottavat byrokratian ei-toivottuja seurauksia. Tukipäätöksentekijän harkintavalta on liian vähäinen pystyäkseen ottamaan huomioon maaseudun nopeasti muuttuvan toimintaympäristön ja tarvittavat erityispiirteet päätöstä tehdessään. Tutkimuksen tulokset tukevat Uusikylän ja kumppaneiden (2018) ja Karhisen (2019) esiin nostamaa tarvetta neuvonnan lisäämisestä viranomaistoiminnassa. Viranomaisten panostaminen ennalta tapahtuvaan neuvontaan valvonnan sijasta, tuottaisi vaikuttavampaa yritystukien toimeenpanoa ja vähentäisi byrokratian ei-toivottuja seurauksia.

Tarastin (2016) selvityksessä todetaan, että maaseutuhallinto yksinkertaistuu yhden toimijatason vähentyessä siirtämällä tehtävät kunnista ja ELY-keskuksista pääosin maakuntien hoidettavaksi. Maaseutuhallinnon rakenteita on uudistettu 2000-luvulla, mutta pelkkä rakenteiden uudistaminen ei riitä byrokratian haittojen vähentämiseen. Tärkeä kysymys on, kuka hallitsee olemassa olevaa byrokraattista järjestelmää. Tutkimuksessa tunnistetut diskurssit korostavat Weberin $(1980,41)$ näkemystä siitä, että yksilö on merkityssisältöisen toiminnan ainoa harjoittaja. Toiminnalla Weber tarkoittaa ihmisen käyttäytymistä, ulospäin ilmenevää tai sisäistä tekemistä, tekemättä jättämistä tai suostumusta. Tämän tutkimuksen tulokset vahvistavat, että byrokratia on viime kädessä palautettavissa yk- 
silöiden toiminnaksi, sillä sekä ongelmien määrittelyt että niiden ratkaisut, kuten myös maaseutuhallinnon tuki- ja tietojärjestelmät ovat ihmisten tekemiä (vrt. Salminen \& Kuoppala 1983; Vihinen 2001).

Kriittinen diskurssianalyysi tähtää diskurssin muuttumiseen eli emansipatioon todellisuuden tietoiseksi tekemällä. Yrittäjien ja viranomaisten hallinnollisen taakan keventämiseksi tuki- ja

\section{LÄHTEET}

Ahonen, Pertti (1989). Hallinto Hallintana: Hallinnon Teorian Avaimet. Helsinki: Valtionhallinnon kehittämiskeskus.

Alasuutari, Pertti (1996). Toinen tasavalta. Suomi 1946-1994. Tampere: Vastapaino.

Alasuutari, Pertti (2007). Yhteiskunta ja inhimillinen todellisuus. Helsinki: Gaudeamus.

Albrow, Martin (1970). Bureaucracy. London: Pall Mall Press.

Antikainen, Janne, Kahila, Petri, Palviainen, Simo, Pyykkönen, Sinikukka \& Yli-Koski, Maria (2014). Manner-Suomen Maaseudun Kehittämisohjelman 2014-2020 Ennakkoarviointi. Helsinki: Maa- ja metsätalousministeriö.

Arovuori, Kyösti (2015). Political Effectiveness of Agricultural Policies - an Empirical Analysis. Helsinki: Helsingin yliopisto.

Burr, Vivien (2015). Social constructionism. London and New York: Routledge.

Euroopan komissio (2010). Eurooppa 2020: Euroopan unionin kasvu- ja työllisyysstrategia. Haettu sivulta

https://eur-lex.europa.eu/legal-content/FI/ TXT/?uri=LEGISSUM\%3Aem0028.

Fairclough, Norman (1995). Critical Discourse Analysis: The Critical Study of Language. Language in Social Life Series. London: Longman.

Fairclough, Norman (2005). Discourse Analysis in Organization Studies: The Case for Critical Realism. Organization Studies 26(6): 915-939.

Giddens, Anthony \& Robert K., Merton (1987). Sociology: A brief but Critical Introduction. 2nd ed. San Diego: Harcourt Brace Jovanovich.

Harisalo, Risto (2008). Organisaatioteoriat. Tampere: Tampereen yliopisto.

Jokinen, Arja, Juhila, Kirsi \& Suoninen, Eero (2016). Diskurssianalyysi: Teoriat, Peruskäsitteet Ja Käyttö. Tampere: Vastapaino.

Karhinen, Reijo (2019). Uusi alku. Maatalous myös tulevaisuuden elinkeino. Helsinki: Maa- ja metsätalousministeriön julkaisuja 2019:3. tietojärjestelmät tulisi saada työkaluiksi ja ymmärrettäviksi kokonaisuuksiksi. Lakien, asetusten ja ohjeiden sisältö ja niiden toimeenpano tulisi olla tarkoituksenmukaista yrittäjyyden edistämisen kannalta, koska lainkuuliaisuus on kuitenkin pysyvää. Muutokset vaativat kansallista yhteistä tahtoa ja samalla myös vahvaa vaikuttamista Euroopan unionin yhteiseen lainsäädäntöön.

Kivikko, Kari, Karjalainen, Sirpa, Mikander, CarlGustav, Konsala, Heikki, Kukkonen, Timo, Sihvola, Sanna \& Latvala, Piia (2009). Maaseudun yritys- ja hankerahoituksen hallinnollisen taakan vähentäminen - työryhmän selvitys. Helsinki: Työryhmämuistio Maa- ja metsätalousministeriö 2009:12.

Kuhmonen, Tuomas, Keränen, Reijo, Kytölä, Liisa, Salo, Hannu, Arovuori, Kyösti, Pyykkönen, Perttu, Mustonen, Verna \& Ponnikas, Jouni (2009). Manner-Suomen maaseudun kehittämisohjelma 2007-2013. Arviointiraportti vuodelta 2008. Sonkajärvi: Suomen aluetutkimus FAR.

Laki Ruokavirastosta 371/18.5.2018.

Laki Maaseutuvirastosta 666/21.7.2006.

Laki elinkeino-, liikenne- ja ympäristökeskuksista 897/20.11.2009.

Laki maaseutuhallinnon järjestämisestä kunnissa 210/30.3.2010.

Maa- ja metsätalousministeriö (MMM) (2019). Manner-Suomen Maaseudun Kehittämisohjelma 2014-2020. Haettu sivulta http://mmm.fi/maaseutu/manner-suomen-maaseudun-kehittamisohjelma-2014-2020, 26.2.2019.

Merton, Robert K. (1968). Social Theory and Social Structure. (Enl. ed.). New York: The New Press.

Morgan, Gareth (2006). Images of organization. London: Sage Publications, Inc.

Männikkö, Marko \& Paajanen, Visa (2016). Tarkastuskertomus 4/2013. Maatalouden tukihallinto. Jälkiseurantaraportti. Helsinki: Valtiontalouden tarkastusvirasto.

Paajanen, Visa, Siirola, Jani \& Vuorinen, Sami (2013). Maatalouden Tukihallinto. Tuloksellisuustarkastuskertomus. Tarkastuskertomus 4/2013. Helsinki: Valtiontalouden tarkastusvirasto.

Peiponen, Mirva (2007). Arvot Virkamiehen Arjessa. Selvitys Virkamiesetiikan Nykytilasta. Helsinki: Valtiovarainministeriö.

Pietikäinen, Sari (2000). Discourses of Differentiation: Ethnic Representations in 
Newspaper Texts. Jyväskylä: University of Jyväskylä.

Pietikäinen, Sari \& Mäntynen, Anne (2009). Kurssi Kohti Diskurssia. Tampere: Vastapaino.

Pyykkönen, Perttu, Kytölä, Liisa, Kuhmonen, Irene, Ponnikas, Jouni, Keränen, Jouni \& Arovuori, Kyösti (2015). Manner-Suomen Maaseudun Kehittämisohjelman 2007-2013 Jälkiarviointi. Helsinki: Maa- ja metsätalousministeriö.

Salmi, Anita (2003). Ylhäältä annettu todellisuus: Leaderin ja ohjelmallisen aluekehityspolitiikan jäljillä. Vaasa: Vaasan yliopisto.

Salminen, Ari (2004). Hallintotiede. Organisaatioiden hallinnolliset perusteet. Helsinki: Edita Prima Oy.

Salminen, Ari \& Kari Kuoppala (1983). Max Weberin Verstehen-Metodi Hallinnontutkimuksessa. Vaasan Korkeakoulun Julkaisuja. Vol. no 98.

Smith, B.C. (1988). Bureaucracy and Political Power. New York: St. Martin's Press,

Stenvall, Jari, af Ursin, Klaus, Tiihonen, Seppo, Nyholm, Inga \& Airaksinen, Jenni (2016). Julkisen hallinnon kehitys Suomessa. Teoksessa Nyholm, Inga, Stenvall, Jari, Airaksinen, Jenni, Pekkola, Elias, Haveri, Arto, af Ursin, Klaus \& Tiihonen, Seppo. Julkinen hallinto Suomessa, 33-68. Helsinki: Tietosanoma.

Suomela, Kaj (2008). Maatalouden tuki- ja valvontajärjestelmien yksinkertaistamista käsittelevän työryhmän loppuraportti. Helsinki. Työryhmämuistio Maa- ja metsätalousministeriö 2008:12.

Suomen Ympäristökeskus (2018). Kaupunkimaaseutu-luokitus. Haettu sivulta https:// www.ymparisto.fi/kaupunkimaaseutuluokitus, 25.4.2018.

Tarasti, Lauri, Kouki, Sami, Saarinen, Mikko, Ryyppö, Outi, \& Sihvola, Sanna (2016). Valtion aluehallinnon ja maakuntahallinnon uudistaminen - lukuunottamatta sosiaali- ja terveydenhuollon uudistamista. Helsinki: Valtiovarainministeriön julkaisu 2016:3

Tiihonen, Seppo \& Ylikangas, Heikki (1992). Virka, Valta, Kulttuuri. Suomalaisen hallintokulttuurin kehitys. Helsinki: Valtion painatuskeskus.

Tuomi, Jouni \& Sarajärvi, Anneli (2009). Laadullinen Tutkimus Ja Sisällönanalyysi. Helsinki: Tammi.

Uusikylä, Petri, Alasuutari, Noora \& Rantala, Kati (2018). Yrityksiin kohdistuva sääntelytaakka: kritiikki painottuu ongelmiin toimeenpanossa.
Helsinki: Valtioneuvoston selvitys- ja tutkimustoiminta.

Uusitalo, Eero (2009a). Maaseutu - väliinputoajasta vastuunkantajaksi: Maaseutupolitiikan itsenäistyminen alue- ja maatalouspolitiikan puristuksessa. Mikkeli: Helsingin yliopisto, Ruraliainstituutti.

Uusitalo, Eero (2009b). Maaseutupolitiikka - neljän toimijaryhmän yhteisöllisyyttä. Maaseudun uusi aika 3/2009, 69-74.

Valtioneuvoston kanslia (2015). Ratkaisujen Suomi Pääministeri Juha Sipilän hallituksen strateginen ohjelma 29.5.2015. Hallituksen julkaisusarja $10 / 2015$.

Vartola, Juha (1979). Valtionhallinnon Rakenteellisen Muutoksen Ongelmasta: Tutkimus Julkishallinnon Kriisiteeseistä Ja Max Weberin Byrokratiateoriasta Sekä Näiden Välisistä Suhteista Valtionhallinnon Rakenteellisen Muutoksen Ongelman Valossa. Tampere: Tampereen yliopisto.

Vihinen, Hilkka (2014). Euroopan unionin maatalous- ja maaseutupolitiikka. Teoksessa Mykkänen, Juri \& Paakkunainen, Kari, Johdatus Euroopan unionin politiikkaan. Helsingin yliopisto: Politiikan ja talouden tutkimuksen laitoksen julkaisuja 2014:16.

Vihinen, Hilkka (2001). Recognising Choice: A Study of the Changing Politics of the Common Agricultural Policy through an Analysis of the MacSharry Reform Debate in Ireland and the Netherlands. Helsinki: MTT. Taloustutkimus (MTTL). Julkaisuja 99.

Viinamäki, Olli-Pekka, Hyyryläinen, Esa, Vainio, Arttu \& Metsälä, Riia (2013). Euroopan Unionin Leader- Toimintatavan Hallinnon Haasteet ja Kehittämisen Vaihtoehdot: Vertailevia $\mathrm{Ha}$ vaintoja Seitsemästä EU-Maasta. Vaasa: Vaasan yliopiston julkaisuja.

Weber, Max (1978a). Economy and Society: An Outline of Interpretive Sociology, 1. Vol. 1. Berkeley: University of California Press.

Weber, Max (1978b). Economy and Society: An Outline of Interpretive Sociology, 2. Vol. 2. Berkeley: University of California Press.

Weber, Max (1980). Basic concepts in sociology (8. pr.). Secaucus, N. J.: Citadel.

Wodak, Ruth (2004). Critical Discourse Analysis. Teoksessa Seale, Clive, Gobo, Giampietro, Gubrium, Jaber F. \& Silverman, David, Qualitative Research Practice, 197-213. London: Sage Publications. 